\title{
Presence Of Left Ventricular Non Compaction In Hypertrophic Cardiomyopathy Is Associated With Arrhythmia
}

\author{
Ganesh Kumar Gnanappa ${ }^{1,2^{*}}$, Preeti Choudhary ${ }^{4,3}$, Linda Lin ${ }^{3,4}$, Chi Jen Hsu, ${ }^{5,4}$, Caroline Medi ${ }^{3,4}$, Stuart Grieve ${ }^{3,4}$, \\ David Celermajer ${ }^{3,4}$, Chris Semsarian ${ }^{3,4}$, Raj Puranik $k^{3,4}$
}

From 19th Annual SCMR Scientific Sessions

Los Angeles, CA, USA. 27-30 January 2016

\section{Background}

Cardiac magnetic resonance (CMR) imaging allows accurate assessment of ventricular compaction. We aimed to determine whether left ventricular non-compaction (LVNC) is related to increased incidence of arrhythmia in adults with Hypertrophic cardiomyopathy (HCM).

\section{Methods}

58 consecutive HCM patients referred for CMR between 2008-2014 were recruited. Only patients with intermediate ventricular thickness of 15-29 mm were included. Patients with apical HCM, severe LV outflow tract obstruction (resting gradient $>50 \mathrm{mmHg}$ ) and significant loading conditions, such as aortic stenosis or hypertension, were excluded. LVNC was diagnosed as per Petersen's criteria.

\section{Results}

$66 \%$ of the patients were male, mean age $52 \pm 18$ years, mean wall thickness was $19 \pm 4 \mathrm{~mm}$. Amongst the 9 patients with LVNC, 5 had VT/VF, 2 had SVT and 2 had syncope. Patients with LVNC had a significantly higher prevalence of ventricular arrhythmia than those without $\mathrm{LVNC}$ ( $56 \%$ vs $18 \%, \mathrm{p}=0.03$ ), with a relative risk of 3.0 (95\% CI $1.3-6.9)$. LV septal thickness (18.4 \pm $5.6 \mathrm{~mm}$ vs $18.7 \pm 3.5 \mathrm{~mm}, \mathrm{p}=0.9$ ) and ejection fraction $(70 \pm 7.7$ vs $70 \pm 10.5 \%, p=0.9)$ did not significantly differ between those with LVNC and those without. Presence of LV scar assessed by late gadolinium enhancement was similar between the groups ( $89 \%$ vs $73 \%, \mathrm{p}=0.7$ ).

'Paediatric cardiology, Children Hospital at Westmead, Kingsford, NSW,

Australia

Full list of author information is available at the end of the article

\section{Conclusions}

Presence of LVNC may be associated with ventricular tachyarrhythmia in HCM patients and may provide a new phenotypic marker for adverse prognosis, especially in the intermediate risk group. Further studies in larger populations are required to assess its possible prognostic value.

\section{Authors' details}

'Paediatric cardiology, Children Hospital at Westmead, Kingsford, NSW, Australia. ${ }^{2}$ Cardiovascular magnetic resonance Sydney, Sydney, NSW, Australia. ${ }^{3}$ Royal Prince Alfred Hospital, Sydney, NSW, Australia. ${ }^{4}$ The University of Sydney, Sydney, NSW, Australia. ${ }^{5}$ Cardiology, Black Town Hospital, Sydney, NSW, Australia.

Published: 27 January 2016

\section{doi:10.1186/1532-429X-18-S1-P298}

Cite this article as: Gnanappa et al:: Presence Of Left Ventricular Non Compaction In Hypertrophic Cardiomyopathy Is Associated With Arrhythmia. Journal of Cardiovascular Magnetic Resonance 2016 18(Suppl 1): P298.

Submit your next manuscript to BioMed Central and take full advantage of:

- Convenient online submission

- Thorough peer review

- No space constraints or color figure charges

- Immediate publication on acceptance

- Inclusion in PubMed, CAS, Scopus and Google Scholar

- Research which is freely available for redistribution 